\title{
Chemical Mutagenesis Breeding of Protoplast of Ammonia-oxidizing Bacteria
}

\author{
Yuwei Dong, Jingzhi Miao, Shirong Tang, Shanglong Chen, Yonghua Wu \\ Xuzhou Institute of Technology, Xuzhou, 221116, P.R. China
}

\begin{abstract}
Strain with strong capacity of ammoxidation screened by repeated enrichment and separation methods from activated sludge which was collected from sewage treatment plant in China university of mining and technology. Lithium chloride and ethidium bromide mutagenesis methods of ammonia-oxidizing bacteria protoplast were used to breed mutant strain with strong capacity of ammoxidation. The relationship between concentrations of chemical mutagens and capacity of ammoxidation were researched. The results showed that regenerated colony number of protoplast decreased with increased lithium chloride or ethidium bromide mutagenic concentration. After culvation of $1 \mathrm{~L}$ simulation sewage medium, the mutagenic strain LC002, mutated by $2.5 \mathrm{mg} / \mathrm{mL}$ lithium chloride, still had better capacity of ammoxidation with $86.89 \%$ removal rate of ammonia nitrogen. The mutagenic strain EB003, mutated by 2 $\mu \mathrm{g} / \mathrm{mL}$ ethidium bromide, also had better capacity of ammoxidation with $85.67 \%$ removal rate of ammonia nitrogen. Protoplast mutagenisis was an effective breeding method to breed excellent ammonia-oxidizing bacteria for further application.
\end{abstract}

Keywords-ammonia-oxidizing bacteria; protoplast; mutagenesis; lithium chloride; ethidium bromide.

\section{INTRODUCTION}

Ammonia-oxidizing bacteria belong to one of physiological subsets of nitrifying bacteria family[1]. They are played a part in first rate limiting step of nitrification $[2,3]$, amine oxidized to nitrites and widely used in denitrification of industrial wastewater and soil[4,5]. However ammonia-oxidizing bacteria, as autotrophic microorganism, had long generation time, slow growth rate, sensitive and easy be eliminated [6]. The question how to improve capacity of ammoxidation of ammonia-oxidizing bacteria need to be answered. Mutagenisis is an effective breeding method, for example protoplast mutagenisis and chemical mutagenesis [7]. Here the strains with strong capacity of ammoxidation were screened by chemical mutagenisis of protoplast method.

\section{MATERIALS AND METHODS}

\section{A. Materials}

Strains. Ammonia-oxidizing bacteria, screened from activated sludge which was collected from sewage treatment plant in China university of mining and technology, had 98\% homology with Nitrosomonas sp. GH22.

Methods
Culture medium. Reference hydrobiology experimental methods [8].

Isolated medium: solution I :3.33\% $\left(\mathrm{NH}_{4}\right)_{2} \mathrm{SO}_{4}, 1.4 \%$

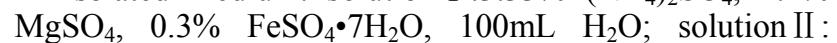
$1.36 \% \mathrm{KH} 2 \mathrm{PO} 4, \quad 100 \mathrm{~mL} \quad \mathrm{H}_{2} \mathrm{O}$; I : II =9:1, pH 8.0-8.2, $0.8 \% \mathrm{CaCO}_{3}, 2 \%$ agar.

Regenerated medium: isolated medium with $0.46 \mathrm{~mol} / \mathrm{L}$ sucrose, $1.5 \%$ polyvinylpyrrolidone and $0.02 \mathrm{~mol} / \mathrm{L}$ $\mathrm{MgCl}_{2} \bullet 6 \mathrm{H}_{2} \mathrm{O}$.

Protoplast dilution: $5 \mathrm{mmol} / \mathrm{L}$ EDTA, $0.5 \mathrm{~mol} / \mathrm{L}$ phosphate buffer, $0.46 \mathrm{~mol} / \mathrm{L}$ sucrose, $0.02 \mathrm{~mol} / \mathrm{L}$ $\mathrm{MgCl}_{2} \bullet 6 \mathrm{H}_{2} \mathrm{O}$.

Simulation sewage medium: $0.08 \%\left(\mathrm{NH}_{4}\right)_{2} \mathrm{SO}_{4}, 0.1 \%$ $\mathrm{K}_{2} \mathrm{HPO}_{4}, 0.05 \% \mathrm{MgSO}_{4}, 0.2 \% \mathrm{NaCl}, 0.04 \% \mathrm{FeSO}_{4}, 0.5 \%$ $\mathrm{CaCO}_{3}, \mathrm{pH} 8.0-8.2, \mathrm{NH}_{3}-\mathrm{N}$ concentration was $206 \mathrm{mg} / \mathrm{L}$.

\section{B. Methods}

Chemical Mutagenesis and regeneration of protoplast.Ammonia-oxidizing bacteria were cultured at the sixth day. Final concentration of ampicillin sodium was $80 \mu \mathrm{g} / \mathrm{mL}$, reaction time of ampicillin sodium was 8 hours, final concentration of lysozyme was $1 \mu \mathrm{g} / \mathrm{mL}$, hydrolysis temperature of lysozyme was $40^{\circ} \mathrm{C}$, hydrolysis time of lysozyme was 30 minutes. Prepared protoplast was cleaned 2 or 3 times by protoplast diluent and then inoculated on regenerated medium which contained $0.01-1 \mathrm{mg} / \mathrm{mL}$ lithium chloride or $0.1-10 \mu \mathrm{g} / \mathrm{mL}$ ethidium bromide. Mutagenic colonies were cultured at $24^{\circ} \mathrm{C}$ for 14 days. After being calculated fatality rate.

Fatality rate $(\%)=($ regenerated colony number of nonmutagenic protoplast- regenerated colony number of mutagenic protoplast) / regenerated colony number of nonmutagenic protoplast

The colony with fast growth and major diameter was inoculated in enriched medium and cultured at $24^{\circ} \mathrm{C}, 110$ $\mathrm{r} / \mathrm{min}$ of shaking flask culture for 14 days. Then centrifuged deposit was added to simulated sewage medium and cultured at $24^{\circ} \mathrm{C}, 110 \mathrm{r} / \mathrm{min}$ of shaking flask culture for 14 days.

Enlarge cultivation for mutagenic strains. Mutagenic strains with faster growth and better nitrite nitrogen enrichment ability were cultured in large scale from 250 to $1000 \mathrm{~mL}$ simulation sewage medium.

Determination method. Reference Analysis method of water and wastewater monitoring methods [9].

Nitrite nitrogen content determination: $\alpha$-naphthylamine spectrophotometry.

Nitrate nitrogen content determination: phenol disulfonic acid spectrophotometry. 
Ammonia nitrogen content determination: Nessler's reagent spectrophotometry.

Bacterial concentration measurement: Most Probable Number method (MPN).

\section{RESULTS AND DISCUSSION}

A. Lithium chloride, ethidium bromide mutagenic conditions of protoplast

Relationship between lithium chloride, ethidium bromide mutagenic concentration and fatality rate of protoplast

Regenerated colony number of protoplast decreased with increased lithium chloride or ethidium bromide mutagenic concentration. Fatality rate was $18.2 \%$ under the $0.1 \mathrm{mg} / \mathrm{mL}$ lithium chloride, $73.1 \%$ under $2.5 \mathrm{mg} / \mathrm{mL}$ and as high as 98.7 under $10 \mathrm{mg} / \mathrm{mL}$. Fatality rate was $19.1 \%$ under the $0.1 \mu \mathrm{g} / \mathrm{mL}$ lithium chloride, $70.1 \%$ under $2 \mu \mathrm{g} / \mathrm{mL}$ and as high as 99.5 under $10 \mu \mathrm{g} / \mathrm{mL}$ (Fig.1).

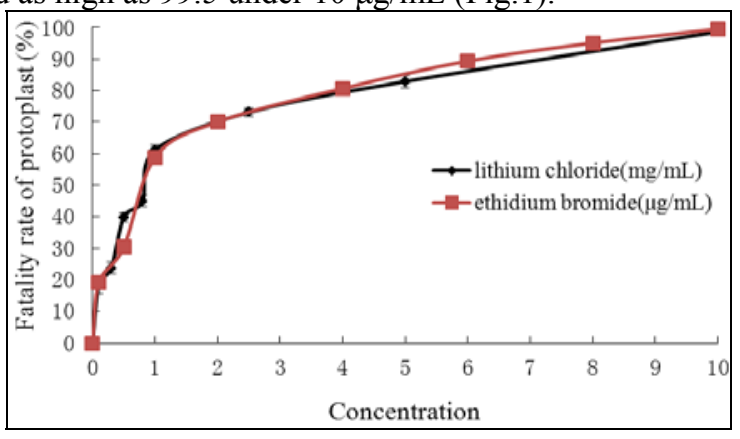

Figure 1. Effects of lithium chloride, ethidium bromide mutagenic concentration on fatality rate of protoplast

Regenerated colonial morphology of protoplast after mutagenesis

The white and small regenerated colonies of protoplast appeared after 8 days cultivation of $0.1 \mathrm{mg} / \mathrm{mL}, 0.3 \mathrm{mg} / \mathrm{mL}$, $0.5 \mathrm{mg} / \mathrm{mL}$ and $0.8 \mathrm{mg} / \mathrm{mL}$ lithium chloride mutagenesis. The white, bigger and less regenerated colonies of protoplast appeared after 7 days cultivation of $1 \mathrm{mg} / \mathrm{mL}$ and $2.5 \mathrm{mg} / \mathrm{mL}$ lithium chloride mutagenesis (Fig.2, I ). The white, smaller and few regenerated colonies of protoplast appeared above 14 days cultivation of $5 \mathrm{mg} / \mathrm{mL}$ and 10 $\mathrm{mg} / \mathrm{mL}$ lithium chloride mutagenesis(Fig.2, II ).

The white and small regenerated colonies of protoplast appeared after 9 days cultivation of $0.1 \mu \mathrm{g} / \mathrm{mL}$ and 0.5 $\mu \mathrm{g} / \mathrm{mL}$ ethidium bromide mutagenesis. The white, bigger and less regenerated colonies of protoplast appeared after 8 days cultivation of $1 \mu \mathrm{g} / \mathrm{mL}, 2 \mu \mathrm{g} / \mathrm{mL}, 4 \mu \mathrm{g} / \mathrm{mL}$ and $6 \mu \mathrm{g} / \mathrm{mL}$ ethidium bromide mutagenesis(Fig.2 III, IV). The white, smaller and few regenerated colonies of protoplast appeared above 18 days cultivation of $8 \mu \mathrm{g} / \mathrm{mL}$ and $10 \mu \mathrm{g} / \mathrm{mL}$ lithium chloride mutagenesis.
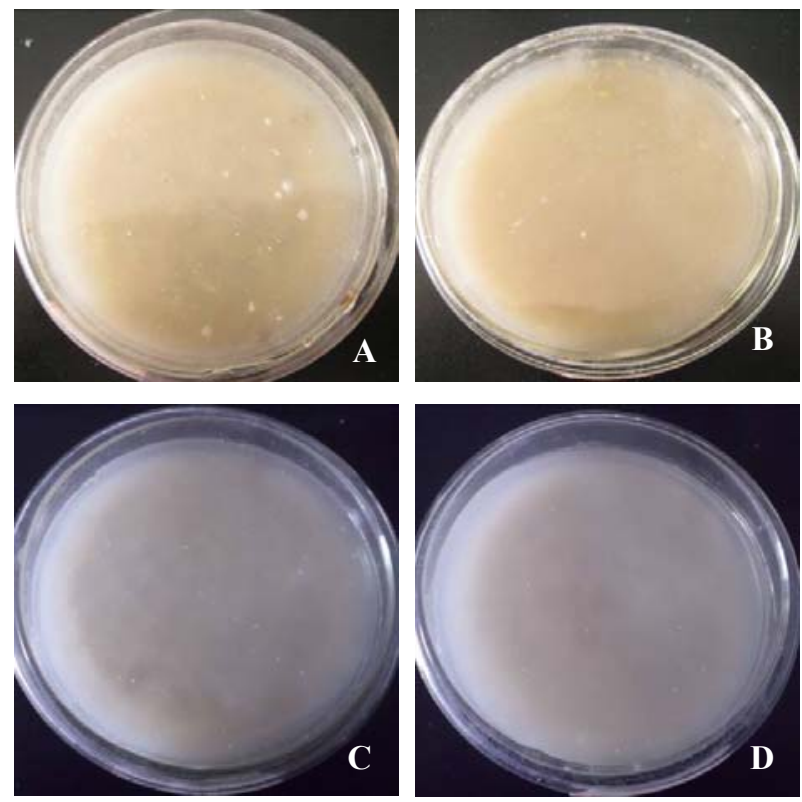

I : $2.5 \mathrm{mg} / \mathrm{mL}$ lithium chloride mutagenesis; II : $5 \mathrm{mg} / \mathrm{mL}$, lithium chloride mutagenesis; III: $1 \mu \mathrm{g} / \mathrm{mL}$ ethidium bromide mutagenesis; IV: 2 $\mu \mathrm{g} / \mathrm{mL}$ ethidium bromide mutagenesis

Figure 2. Regenerated colonial morphology of protoplast after mutagenesis

\section{B. Determination of nitrite nitrogen concentration}

Fast-growing and big regenerated colonies of protoplast were selected. So non-mutagenic strain (LC000) and the lithium chloride mutagenic strains of $1 \mathrm{mg} / \mathrm{mL}, 2.5 \mathrm{mg} / \mathrm{mL}$, $5 \mathrm{mg} / \mathrm{mL}, 10 \mathrm{mg} / \mathrm{mL}$ were named as LC001, LC002, LC003, LC004. The ethidium bromide mutagenic strains of $0.5 \mu \mathrm{g} / \mathrm{mL}, 1 \mu \mathrm{g} / \mathrm{mL}, 2 \mu \mathrm{g} / \mathrm{mL}, 4 \mu \mathrm{g} / \mathrm{mL}$ and $6 \mu \mathrm{g} / \mathrm{mL}$ were named as EB001, EB002, EB003, EB004 and EB005. They are cultured in $140 \mathrm{~mL}$ simulation sewage medium. Concentration of nitrite nitrogen was determined everyday.

Nitrite nitrogen concentration of non- mutagenic strain and mutagenic strains increased firstly and then smoothly with increased cultivation time. The highest nitrite nitrogen concentration of lithium chloride mutagenic strains was strain LC002 with $175.55 \mathrm{mg} / \mathrm{L}$ (Fig.3a). The highest nitrite nitrogen concentration of ethidium bromide mutagenic strains was strain EB003 with $175.23 \mathrm{mg} / \mathrm{L}$ (Fig.3b). Hereditary character of lithium chloride mutagenic strains LC001 and LC004, ethidium bromide mutagenic strains EB004 and EB005 were instable and removed. 


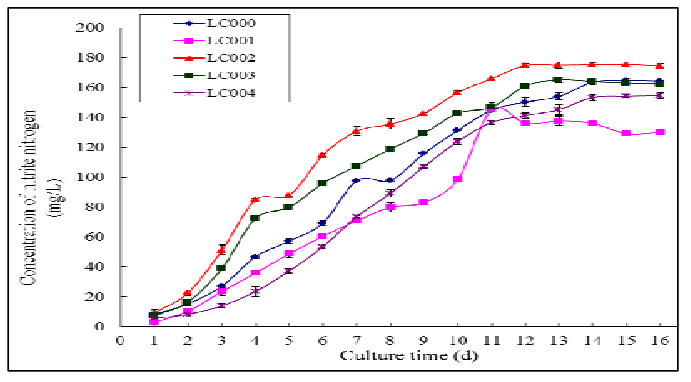

a

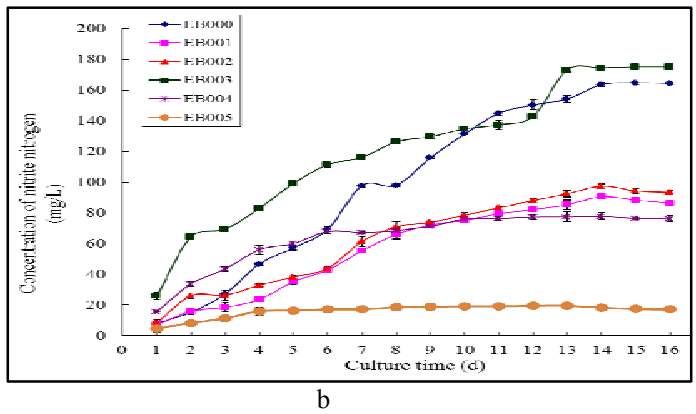

Figure 3. a) Nitrite nitrogen concentration of strains LC000, LC001,

LC002, LC003 and LC004 (140 mL simulation sewage medium) b) Nitrite nitrogen concentration of strains EB000, EB001, EB002, EB003, EB004 and EB005 (140 mL simulation sewage medium)

Large scale cultivation. The higher nitrite nitrogen concentration of strains LC002, LC003, EB001, EB002, EB003 and strains LC000, EB000 were cultured in $250 \mathrm{~mL}$ simulation sewage medium. Concentration of nitrite nitrogen was determined.
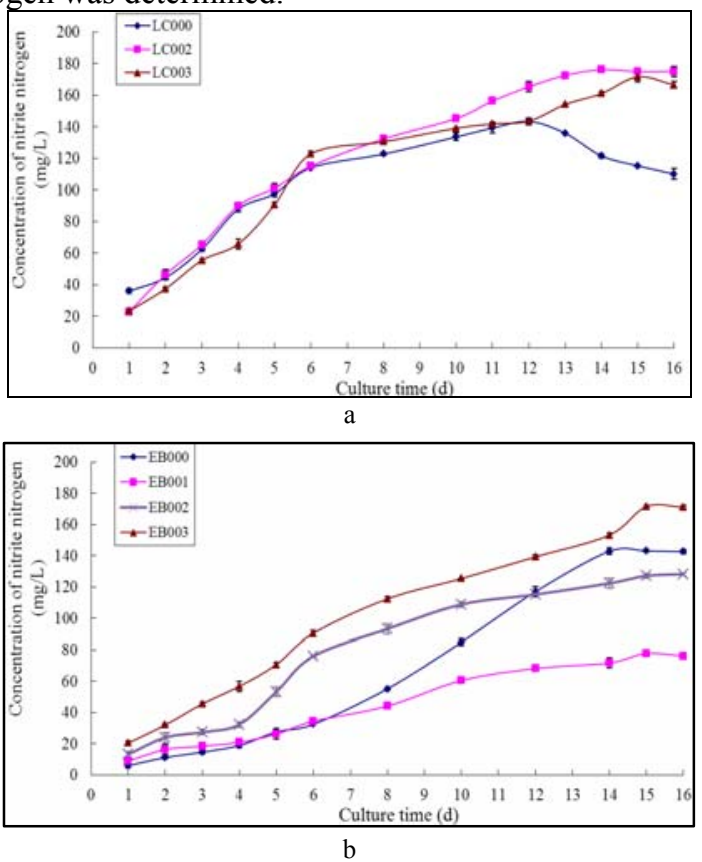

Figure 4. a) Nitrite nitrogen concentration of strains LC000, LC002 and LC003 (250 mL simulation sewage medium)

b) Nitrite nitrogen concentration of strains EB000, EB001, EB002and EB003 (250 $\mathrm{mL}$ simulation sewage medium)
Nitrite nitrogen concentration of non- mutagenic strain and mutagenic strains increased firstly and then smoothly with increased cultivation time. The highest nitrite nitrogen concentration of lithium chloride mutagenic strains was strain LC002 with 176.18 (Fig.4a). The highest nitrite nitrogen concentration of ethidium bromide mutagenic strains was strain EB003 with $171.57 \mathrm{mg} / \mathrm{L}$ (Fig.4b). Hereditary character of ethidium bromide mutagenic strains EB001 and EB002 were instable and removed.

The strains LC000, LC002, LC003, EB000 and EB003 were cultured in $500 \mathrm{~mL}$ simulation sewage medium. Concentration of nitrite nitrogen was determined.

Hereditary character of strain LC002 and EB003 were stable with the higher nitrite nitrogen concentration, $178.89 \mathrm{mg} / \mathrm{L}$ and $168.95 \mathrm{mg} / \mathrm{L}$, respectively, after $500 \mathrm{~mL}$ Large scale cultivation. The strain LC003 was removed with the lower nitrite nitrogen concentration (Fig.5).
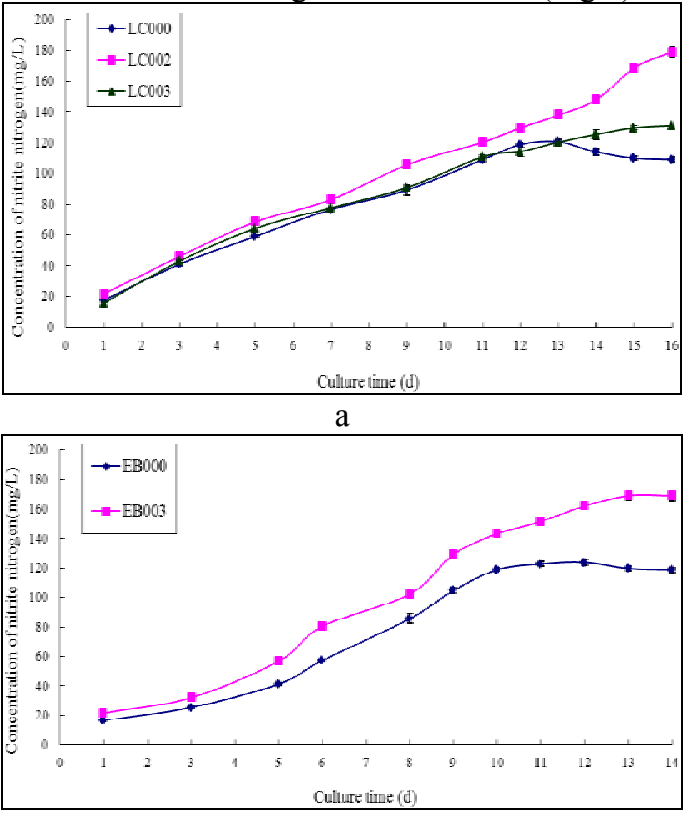

Figure 5. a) Nitrite nitrogen concentration of strains LC000, LC002 and LC003 (500 mL simulation sewage medium)

b) Nitrite nitrogen concentration of strains EB000 and EB003 $(500 \mathrm{~mL}$ simulation sewage medium)

C. Capacity of ammoxidation of strains LC002 and EB003

The strain LC002 and EB003 were cultured in $1 \mathrm{~L}$ simulation sewage medium. Concentrations of nitrite nitrogen concentration, nitrate nitrogen concentration and ammonia nitrogen concentration were determined. Afer $1 \mathrm{~L}$ simulation sewage medium culture, removal rate of ammonia nitrogen of strains LC002 and EB003, reached $86.89 \%$ and $85.67 \%$ respectively, with lower concentration of nitrate nitrogen concentration and faster grow rate than before.

Bacterial concentration of strains LC002 and EB003 were determined by MPN and reached $2.3 \times 107 \mathrm{cfu} / \mathrm{mL}$ after 11 days cultivation (Table I). 
TABLE I. BACTERIAL CONCENTRATION OF STRAINS LC002 AND EB003

\begin{tabular}{|c|c|c|c|c|c|c|}
\hline \begin{tabular}{|l|} 
Culture \\
time (d)
\end{tabular} & 1 & 2 & 3 & 4 & 5 & 6 \\
\hline $\begin{array}{l}\text { Number } \\
\text { (cfu/mL) } \\
\text { of strain } \\
\text { LC002 }\end{array}$ & 54 & 121 & 810 & $1.7 \times 10^{3}$ & $8.9 \times 10^{3}$ & $2.1 \times 10^{5}$ \\
\hline $\begin{array}{l}\text { Number } \\
\text { (cfu/mL) } \\
\text { of strain } \\
\text { EB003 }\end{array}$ & 36 & 97 & 390 & $0.5 \times 10^{3}$ & $4.9 \times 10^{3}$ & $0.7 \times 10^{5}$ \\
\hline \begin{tabular}{|l|} 
Culture \\
time (d)
\end{tabular} & 7 & 8 & 9 & 10 & 11 & \\
\hline $\begin{array}{l}\text { Number } \\
\text { (cfu/mL) } \\
\text { of strain } \\
\text { LC002 }\end{array}$ & $3.1 \times 10^{5}$ & $4.5 \times 10^{5}$ & $2.3 \times 10^{6}$ & $3.5 \times 10^{6}$ & $2.3 \times 10^{7}$ & \\
\hline $\begin{array}{l}\text { Number } \\
\text { (cfu/mL) } \\
\text { of strain } \\
\text { EB003 }\end{array}$ & $1.0 \times 10^{5}$ & $2.1 \times 10^{5}$ & $0.5 \times 10^{6}$ & $1.8 \times 10^{6}$ & $0.2 \times 10^{7}$ & \\
\hline
\end{tabular}

Overall, the strains LC002 and EB003 had better capacity of ammoxidation with fatality rate $73.1 \%$ and $70.1 \%$ respectively (Fig. 1). Mutagenic strain with fatality rate $70 \%-75 \%$ had higher forward mutation probability( Zhou, 1998). Our results were in accordance with reported data. Strains LC002 and EB003 will be used for coming research.

\section{CONCLUSION}

1. After cultivation of $25 \mathrm{~mL}, 500 \mathrm{~mL}$ and $1 \mathrm{~L}$ simulation sewage medium, the mutagenic strain LC002, mutated by $2.5 \mathrm{mg} / \mathrm{mL}$ lithium chloride and the mutagenic strain EB003, mutated by $2 \mu \mathrm{g} / \mathrm{mL}$ ethidium bromide, still had better capacity of ammoxidation with $86.89 \%$ and $85.67 \%$ removal rate of ammonia nitrogen respectively.

\section{ACKNOWLEDGEMENTS}

This research was supported by grants from the Natural Science Foundation of Jiangsu Province (BK2011201).

\section{REFERENCES}

[1] Woses, C.R., Weisburg W.G. \& Paster B.J., The phylogeny of purple baeteria: the alpha subdivision. Systematic and Applied Microbiology, 5(3), pp.327-336, 1984.

[2] Deboer W., Gunnewiek P.J.A.K. \& Veenhuis M., Nitrification at low $\mathrm{pH}$ by aggregated chemolithotrophic bacteria. Applied and Environmental Microbiology, 57, pp.3600-3604, 1991.

[3] Liu Z.P. \& Liu S.J. Advances in the molecular biology of nitrifying microorganisms. Chin J Appl Environ Biol, 10 (4), pp. 521-525, 2004.

[4] Hu J.L., Lin X.G. \& Chu H.Y., Isolation of soil ammonia-oxidizing bacteria. Soils, 37(5), pp. 569-571, 2005.

[5] Yu J., Yang M., Qi R. \& Zhou J., Community structures of ammoniaoxidizing bacteria in different municipal wastewater treatment systems. Acta Scientiae Circumstantiae, 29(3), pp. 521-526, 2009.

[6] Werner D. \& Newton W.E., Nitrogen Fixation in Agriculture Forestry, Ecology, and the Environment. 1st ed, Netherlands: Springer, pp. 255-276, 2005.

[7] Li Y.Z., Wang P. \& Liao X.H., Mutation breeding with chemi-physical methods by aerobic denitrifiers. Environmental Science and Technology, 33(3), pp. 14-17, 2010.

[8] Chen S.M. \& Zheng F.S., Hydrobiology experimental methods. Beijing: oceanpress, pp. 80-85, 1985.

[9] China environmental protection administration. Analysis method of water and wastewater monitoring. Beijing: China Environmental Science Press, 2002.

[10] Zhou J.C. Microbial genetics. Beijing: China Agriculture Press, pp.152- 154,1998 . 